Malaguti, S. - Antes da queda do Muro

\title{
Antes da Queda do Muro, além dele e sem ele: A estética emergente em Die neuen Leiden...
}

\begin{abstract}
This article is an analysis of the novel Die neuen Leiden des jungen W. (1973) in the light of its intertextuality with Goethe's, Defoe's and Salinger's texts. It has been suggested that Plenzdorf's novel creates a stylistic and ideological world, which is instigating for the literary paradigms of the Socialist Realism of the 70s in East Germany. Twenty years after the Fall of the Berlin Wall, this created world in the novel seems to be up-to-date or even paradigmatic for the current representation of German Democratic Republic cultural memory in literature and film. The article then relies on an analysis of intertextuality and intermediality as a method to approach processes of transformation. The different processes inherent to the novel and its pretexts have been reported.
\end{abstract}

Keywords: German literature, German Democratic Republic, processes of transformation, intertextuality, intermediality.

Resumo: Nesta análise do romance Die neuen Leiden des jungen W. (1973) em sua intertextualidade com os romances de Goethe, Defoe e Salinger, sugere-se que o texto de Plenzdorf cria um universo estilístico e ideológico instigante a uma produção inserida no contexto literário do Realismo Socialista dos anos 70 na Alemanha Oriental. Vinte anos após a Queda do Muro de Berlim, esse universo revela-se atual, senão modelar, para o (re)trabalho de memória cultural da RDA representado na literatura e no cinema contemporâneos. Para tanto, recorre-se às análises da intertextualidade como um método de abordagem de processos de transformação. Expõem-se, então, os diferentes processos observados no romance em relação aos seus pré-textos.

Palavras-chave: literatura alemã, República Democrática Alemã, processos de transformação, intertextualidade, intermidialidade.

${ }^{1}$ Graduação na FFLCH-USP e Mestrado no Programa de Língua e Literatura Alemã da FFLCH/USP. Doutorado em Literatura Alemã na Universidade de Kassel, Alemanha. Docência na LMU de Munique. Email: smalaguti@daad-alumni.de 
Malaguti, S. - Antes da queda do Muro

Zusammenfassung: Ziel dieses Beitrags ist die intertextuelle Untersuchung von Plenzdorfs Roman Die neuen Leiden des jungen W. (1973), unter der Berücksichtigung von Goethes Die Leiden des jungen Werthers (1774), Defoes Robinson Crusoe (1719) und Salingers Der Fänger im Roggen (1951). Daraus ergeben sich interessante stilistische und ideologische Aspekte für einen innerhalb des realsozialistischen Staats verfassten Roman. Diese Aspekte werden 20 Jahre nach dem Fall der Berliner Mauer aktuell, wenn nicht paradigmatisch für eine Generation von Schriftstellern und Kinomachern, die sich nach den untersuchten Betrachtungsweisen mit dem kulturellen Gedächtnis der DDR befassen. Um dieses Ziel zu erreichen, wird Intertextualität als eine Methode für die Beschäftigung mit den Transformationsprozessen betrachtet. Verschiedene Prozesse werden in Bezug auf die Prätexte festgestellt und im Beitrag beschrieben.

Stichwörter: Deutsche Literatur, Deutsche Demokratische Republik, Intertextualität, Transformationsprozesse, Intermedialität

\section{Introdução}

O romance Die neuen Leiden des jungen $W^{2}{ }^{2}$ (1973), de Ulrich Plenzdorf, está inserido na história literária dos anos 70 do Realismo Socialista da República Democrática Alemã. Essa obra é até hoje considerada expressiva e única, pois ilustra, mediante sua estética pop e jocosa, a postura de uma geração de jovens, de escritores e de intelectuais da RDA que, mesmo antes da Queda do Muro de Berlim, já dialogavam com elementos da realidade que existiam além dele.

Aquela geração procurava libertar-se da rigorosa doutrina estética do Realismo Socialista para possibilitar uma renovação social. No caso do romance Die neuen Leiden... essa procura se traduz menos no tom de resistência política e ideológica e mais em traços formais, em mudanças de estilo e em incorporação de conteúdos à ficção, gerados pelo que aqui se denomina de processos de transformação; como o da tradição literária, da estrutura, do estilo, da crítica e da mídia. Trata-se da convivência de "resíduos de outro tipo de produção cultural e literária" com "traços emergentes", típica de sociedades em desestabilização e reorganização na pós-modernidade (PELLEGRINI 2008: 69).

Em relação ao romance aqui analisado, entende-se por "resíduos" primeiramente a representação que este faz da sociedade socialista e, em segundo lugar, as

\footnotetext{
${ }^{2}$ Daqui para frente nos referiremos ao título de forma abreviada: Die neuen Leiden... .
} 
Malaguti, S. - Antes da queda do Muro

incorporações de outros textos ao de Plenzdorf. Desde o início do romance nota-se uma narrativa de fundo tomada do ambiente da Alemanha socialista, do clássico préromântico e da geração beat. Por "traços emergentes" consideramos as características estético-narrativas, com os quais a ficção, de forma inovadora, combina o resíduo, se reorganiza e apresenta uma tendência estético-literária original. Assim, a mistura dos acontecimentos do romance com os elementos intertextuais, da cultura juvenil, da mídia e de outras artes tornam a narração ligeira e divertida, enfraquecendo assim a sociedade opressora e o caráter totalitário do regime do SED (CORNELSEN 2007). Devido a esses traços, reconhecemos no romance de Die neuen Leiden... o emergir de uma forma estética adotada no trabalho de memória cultural da RDA após a Queda do Muro. Alguns títulos, Helden wie wir (1995), Am kürzeren Ende der Sonnenallee (1999) e Mein erstes T-Shirt (2001), obtiveram com essa estética muito reconhecimento. Estratégia semelhante foi adotada em alguns filmes, como Sonnenallee (1999) e Good Bye Lenin! (2003), que alcançaram igualmente sucesso, inclusive internacional, como há muito não acontecia com o cinema alemão.

Partindo da afirmação de que a literatura mantém sempre relações com seu contexto histórico, social e cultural, podendo inclusive, enquanto transforma a si mesma, contribuir para transformar aquele, o presente artigo apresenta, primeiro, o panorâma histórico, literário e cultural da RDA entre os anos 70 até a Queda do Muro, em seguida, esboça as bases de uma incipiente teoria dos processos de transformação e analisa o romance de Ulrich Plenzdorf à sua luz para verificar quais são os resíduos, os traços emergentes e os resultados dessa combinação.

\section{Antes da Queda do Muro, além dele}

Conforme a doutrina estética estabelecida por Stalin em 1932, a literatura dos países socialistas deveria não só cumprir com sua função social enquanto expressão artística, como também de instrumento de utilidade politíco-ideológica. Esperava-se em

primeiro lugar que os escritores se servissem de seus talentos para suscitar o 
Malaguti, S. - Antes da queda do Muro

aprimoramento, a integração e o entusiasmo da vida dos cidadãos na sociedade socialista na figura de um herói, que produzisse no leitor uma fácil identificação.

Diante disso, a característica principal do realismo socialista é a sua "poética normativa determinada por critérios não estéticos" (RöHL 1988: 22). Além disso, a literatura do realismo socialista da RDA foi fortemente influenciada pelas teorias literárias de Lukàcs, que privilegiava a herança dos clássicos e dos realistas alemães, mas hostilizava a decadência, o formalismo e o modernismo na literatura.

Um marco considerável para uma primeira mudança literário-cultural na antiga Alemanha Oriental é o ano de 1971, quando no VIII Congresso do Partido Socialista Unificado e a nova liderança de Erich Honecker sugerem à literatura uma nova perspectiva. Honecker (apud EMMERICH 1981:181) é da opinião de que, partindo-se de uma posição firme baseada no socialismo, não haveria tabus para a arte e a literatura.

Wenn man von den festen Positionen des Sozialismus ausgeht, kann es meines Erachtens auf dem Gebiet von Kunst und Literatur keine Tabus geben. Das betrifft sowohl die Fragen der inhaltlichen Gestaltung als auch des Stils. (EMMERICH 1981: 181) ${ }^{3}$

Mesmo sob a nova política cultural, algumas obras não foram aprovadas pela censura, enquanto outras puderam ser publicadas, como o romance Die neuen Leiden... de Ulrich Plenzdorf .

Esse romance é um exemplo do tipo de prosa que se desenvolveu a partir dos anos 70: o questionamento do indivíduo e suas experiências na sociedade socialista dentro da ex-RDA. Para expressar este conflito pela redescoberta da consciência subjetiva, cunhou-se a expressão "nova subjetividade", que rotula a produção literária de vários autores desta fase não só na RDA, como também na RFA. Normalmente, a postura desses autores é de oposição às normas e aos estilos convencionais, por isso utilizam uma linguagem informal e uma estrutura narrativa pessoal. A literatura pretende uma abordagem subjetiva dentro de temas e tendências atuais ao mesmo tempo em que se utiliza do passado para referências críticas.

\footnotetext{
3 “Ao meu ver, não deve haver tabus nas áreas da arte e da literatura, quando se parte das posições firmes do socialismo. Isso se refere tanto às questões de conteúdo como às de estilo." (Todas as traduções ao longo do texto são de nossa autoria.)
} 
Malaguti, S. - Antes da queda do Muro

O romance de Plenzdorf se insere, portanto, num momento de redescoberta da consciência do indivíduo, que literariamente se traduziu na Alemanha no movimento da "nova subjetividade" e mundialmente, em movimentos culturais como o da contracultura, o dos hippies e dos fãs de rock.

Justamente por se inserir nesse panorama literário e cultural de tendências mais mundiais do que regionais, podemos afirmar que o romance de Plenzdorf é representativo para uma geração dentro da RDA que começou a renovar os rumos literários, artistícos, culturais e políticos. A nova geração literária assumiu a renúncia da estética prescritiva e formalista (inspirada em Lukács), então vingente, em favor de uma estética que enfatizou o caráter comunicativo e dinâmico da relação entre o escritor e a sociedade (inspirada em Brecht). Foi a partir dos anos 70 que a literatura da RDA se rendeu aos princípios de uma teoria comunicativo-ficional, que levou em conta a contribuição do leitor para o efeito artístico na sociedade, em detrimento da propaganda psicológica que sufocou a interatividade com a crítica do receptor. Como resultado, observamos que a literatura da RDA dos anos 70 até o ano da Queda do Muro de Berlim, anos da desestabilização do sistema na RDA, seguiu mais inovadora e ousada, independentemente dos ataques repressivos que sofria em função da falta de perspectivas do falido governo socialista. Mesmo nos últimos anos da era da Glasnost, muitos livros e filmes foram retidos pela censura, ainda desconfiada das promessas de Gorbatschóv.

De qualquer maneira, a política de Gorbatschóv pouco influenciou nas mudanças radicais. Para GRANT (1995), o ponto de partida para a tal renovação foi possível devido à promessa de amenização da política cultural feita por Honecker. Do ponto de vista da literatura, há pelo menos mais três motivos que influenciaram a mudança.

Em primeiro lugar, está a desilusão em relação ao realismo-socialista e à crise que ele gerou entre os escritores e, posteriormente entre eles e os políticos. A expulsão de Biermann foi a confirmação de que não era mais possível um diálogo entre a esfera literária e a autoridade política. Diante de tal situação insustentável, quase sem perspectivas, a produção literária representava sempre um risco para seu autor e se tornava sempre um espaço tenso, porque servia tanto para o desabafo subjetivo, como para a interação do eu com o coletivo. Por isso, esse risco, a crise existencial e a desilusão são temas recorrentes na literatura desse período, que formalmente exigiam 
Malaguti, S. - Antes da queda do Muro

estruturas que eliminassem a estabilidade, a unidade e a autoridade narrativa. A escrita não-linear, a perspectiva múltipla, o monólogo interior e a subversão de regras sintáticas são incorporados à literatura. GRANT (1995) analisa essas inovações como intencionais por parte dos escritores que reconheciam na inovação e na ruptura da comunicação literária uma maneira de chamar a atenção da sociedade para os anos da desestabilização.

O segundo motivo relevante para entender a literatura dos anos 70 e 80 na RDA é a discussão dos privilégios que os escritores gozavam dentro da república, quase falida. De fato, tal questão agravava a crise existencial dos escritores, pois para alguns como Heiner Müller - o "privilégio" de ser escritor e ser mais recompensado por isso, os colocava em uma situação diferente da maioria dos cidadãos e denunciava uma falha nos princípios socialistas daquele país. Para outros escritores, entretanto, como Erich Köhler, o privilégio era um pré-requisito para gerar o diálogo entre os cidadãos comuns e os intelectuais.

O terceiro motivo que influencia a criação de uma nova literatura contemporânea da RDA é a formação de novos escritores, a exemplo de Uwe Kolbe, Bert PapenfußGorek, Elke Erb, Steffen Mensching, que articulavam em consonância com vários programas estéticos (dadaísmo, futurismo) e movimentos sociais (punk, ecológico) principalmente em seus textos líricos. Como não aceitavam os parâmetros ditados pelo Partido Socialista, os novos escritores optaram por não se exporem muito ao público, a fim de garantir o desenvolvimento de seus projetos. Como resultado, verifica-se dos anos 70 até nos últimos anos da literatura da RDA uma diversificação radical das formas poéticas, do conceito de literatura e do seu relacionamento com o público leitor. HÄHNEL (1985: 18) resume essa mudança da seguinte maneira:

[Der Prozeß] läßt sich nicht nur in einem Nebeneinander und im „Diffundieren“ unterschiedlicher Prosagenres ausmachen, sondern reicht von der Verschiedenheit, ja Gegensätzlichkeit bestimmter Autorengruppen und generationen bis zu unterschiedlichen Ansichten von der Funktion der Literatur und entsprechenden Strategien des Schreibens, zu Auffassungen vom 
Malaguti, S. - Antes da queda do Muro

literarischen Helden, zu Erwartungen der Leser an Literatur und dem Gebrauch, den sie von neuen Werken machen. ${ }^{4}$

Em seguida, apresentamos como a teoria da intertextualidade e os processos de transformação contribuem para uma leitura de formas poéticas inovadoras no contexto literário, no qual o romance de Plenzdorf está inserido.

\section{Intertextualidade, ponto de partida para uma teoria dos processos de transformação}

Ao justificar a necessidade de um novo pensamento crítico-literário em meados dos anos 60, KRISTEVA (1969: 144) assim apresentou os conceitos de Bakhtin:

Bakhtine est l'un des premiers à remplacer le découpage statique des textes par un modèle où la structure littéraire n'est pas, mais où elle s'élabore par rapport à une autre structure. Cette dynamisation du structuralisme n'est possible qu'à partir d'une conception selon laquelle le "mot littéraire" n'est pas un point (un sens fixe), mais un croisement de surfaces textuelles, un dialogue de plusieurs écritures: de l'écrivain, du destinataire (ou du personnage), du contexte culturel actuel ou antérieur. ${ }^{5}$

Baseada nesses pensamentos, Kristeva reelaborou os conceitos da sua teoria da intertextualidade chegando à afirmação complementar de que todo texto é transformação de um outro texto (KRISTEVA 1969: 146). Tais conceitos constituem o cerne da teoria da intertextualidade, mas sublinham principalmente duas particularidades da condição literária que vinham sendo negligenciadas pelos estruturalistas até então: a sua pluralidade (plusieurs écritures) e a sua concepção

\footnotetext{
4 “[O processo] não é importante somente pela coexistência e difusão de diferentes tipos de prosas, mas também pela diversividade, ou melhor, pelo antagonismo entre determinados grupos e gerações de autores e até pelos pareceres diferentes a respeito da função da literatura e correspondentes estratégias de escritura, do herói literário, das expectativas dos leitores perante a literatura e do uso que eles fazem de novas obras."

5 "Bakhtin é um dos primeiros a substitutir a posição estática do texto para um modelo no qual a estrutura literária elabora-se em relação a uma outra estrutura. Esta dinamização do estruturalismo não é possível a partir de uma concepção segundo a qual "a palavra literária" é um ponto (um sentido fixo), mas de um cruzamento de superfícies textuais, um diálogo de várias escritas: do escritor, do destinatário (ou do personagem), do contexto cultural atual ou anterior."
} 
Malaguti, S. - Antes da queda do Muro

dinâmica ("le mot littéraire n'est pas un point, un sens fixe, mais un croisement"). Ora, essas particularidades citadas por Kristeva vão além da qualidade intertextual, pois dizem respeito à 1) concepção de texto num sentido amplo e 2) a relação de transformação de um texto com os contextos culturais e com outras áreas de conhecimento, como definido por NÖTH (2000: 392):

Text als kulturelle Botschaft: In seiner weitesten Bestimmung umfasst der Textbegriff eine verbale, nonverbale, visuelle und auditive Mitteilung (...). Nicht nur gesprochene und geschriebene Diskurse, sondern auch Filme, Theateraufführungen, Zeremonien, Ballettaufführungen, Happenings, Zirkusnummern, Bilder oder Musikstücke sind danach Texte. ${ }^{6}$

Assim, parece-nos que, a partir da formulação da teoria da intertextualidade, os conceitos de Kristeva esboçam simultanemente o ponto de partida para uma teoria maior dos processos de transformação, na qual, ao lado da própria intertextualidade, podem ser considerados outros fenômenos, como o da intermidialidade, o da interdiscursividade e o da interdisciplinariedade. De certa forma, os conceitos de Bakhtin e os de Kristeva antecipam a proposta dos Cultural Studies que, na sua concepção mais atual (BACHMANN-MEDICK 2007: 197), considera todos os fenômenos acima citados.

A intertextualidade, particularmente, como uma teoria da interpretação de como um texto ou vários se situa(m) ou se relaciona $(m)$ em meio a outros textos, procura também desvelar num modo de interpretação crítica do como tal texto se situa tanto em meio a outros textos e como os transforma. Sendo o texto concebido num amplo sentido (NÖTH 2000), esse modo detecta inevitavelmente relações entre textos de mídias diferentes; portanto, a sua intermidialidade. Como uma prática crítica, a intertextualidade trata os textos como um espaço, dentro do qual a visibilidade de outros textos e contextos, práticas e manifestações sociais, discursivas, culturais, etc. dependerão sempre das possíveis relações que podem ser estabelecidas no e com o

\footnotetext{
6 "Texto como mensagem cultural: em sua concepção mais geral, a definição de texto é uma informação verbal, não verbal, visual e auditiva [...]. Conforme esta concepção, um texto não é somente o discurso falado ou o escrito, mas também filmes, peças teatrais, cerimônias, balés, happenings, números de circo, quadros e músicas."
} 
Malaguti, S. - Antes da queda do Muro

próprio texto literário. É esse aspecto da prática intertextual que abre espaço para o ponto de vista da interdiscursividade e interdisciplinariedade do texto.

A partir desse ponto de vista, o texto literário não afirma, portanto, nada pontualmente e não engessa um único sentido; ele se estabelece e obtém um sentido conforme o ponto de vista de quem o lê, onde, quando e como este o faz (un croisement de l'écrivain, du destinataire (ou du personnage), du contexte culturel actuel ou antérieur). Entendida por JENNY (1979: 45) assim:

A intertextualidade é pois uma máquina perturbadora. Trata-se de não deixar o sentido em sossego - de evitar o triunfo do "cliché" por um trabalho de transformação. Se, com efeito, a remanência cultural alimenta todo e qualquer texto, ela também o ameaça constantemente de se atolar, logo que ceda ao automatismo de associações e se deixe paralisar pela irrupção de estereótipos $[\ldots]$.

Pretendemos aqui analisar o romance Die neuen Leiden..., de Plenzdorf, como um texto no qual a intertextualidade serve para transgredir a norma estética ditada pelo Realismo Socialista, contribuindo assim para uma mudança da norma imposta. Desvelando textos e contextos e suas relações a partir de elementos explícitos inscritos nele, isto é, as transformações em jogo que moldaram seu processo de construção, sugerimos que há, basicamente, os seguintes processos de transformações: 1) transformação da tradição literária, haja vista o resgate de textos-chaves do patrimônio da cultura alemã e universal num momento histórico-literário contemporâneo, 2) transformação estrutural, mediante a qual Plenzdorf busca definir o tipo da sua ficção; 3) transformação estilística, mediante a qual Plenzdorf busca estabelecer um sistema de comunicação ou uma linguagem própria ao seu texto literário ; 4) transformação crítico-comunicativa, mediante a qual Plenzdorf aproveita o texto de Goethe para propor um novo conjunto de ideais perante a realidade objetiva do seu personagem Wibeau e 5) transformação intermedial primária (ou inerente) e secundária, haja vista que, antes de ser publicado, o romance foi primeiramente encenado e, depois de publicado, foi filmado. Além disso, verificam-se diversas menções a mídias diversas através da fala do protagonista Edgar.

No item a seguir, analisaremos o romance de Plenzdorf considerando tais processos de transformação. 


\section{A análise dos processos de transformação no romance Die neuen Leiden des jungen W. de Ulrich Plenzdorf}

Verifica-se no romance Die neuen Leiden... um processo triplo de transformação da tradição literária e cultural. Assim, o romance Die Leiden des jungen Werther de GoETHE (1774) e a literatura pré-romântica do movimento do Sturm und Drang são resgatados, Werther e sua trajetória são atualizados no personagem Wibeau, que vive nos anos 70 da Berlim socialista. Contudo, o clássico de Goethe ainda é retransformado através do diálogo que se estabelece com outros romances mais modernos, com Robinson Crusoe de Defoe (1719) e The Catcher in the Rye de SALINGER (1951). Convergem, portanto, para o texto de Plenzdorf três outros textos da tradição literária. $\mathrm{O}$ ponto de convergência é o jovem e personagem principal Edgar Wibeau, através do qual os três textos clássicos fluem para o de Plenzdorf por meio de citações de excertos dos textos mencionados, de nomes de personagens e seus autores e de comentários críticoreflexivos a respeito dos clássicos.

O enredo de Die neuen Leiden... é simples, pois recupera topos da tradição literária como a fuga juvenil da casa dos pais e o triângulo amoroso, temas encontrados nos clássicos de Goethe, Defoe e Salinger. Edgar Wibeau, de 17 anos e morador de uma localidade da Alemanha Oriental dos anos 70, sai sem avisar da casa materna para morar sozinho, pois, entre a solidão, o emprego e a relação amorosa, procura sua realização pessoal: vagabundear, pintar e meditar. O romance torna-se curioso quando, por acaso, Edgar encontra o romance Die Leiden des jungen Werther, de Goethe, dentro do banheiro do barracão onde está morando. Ao ler o romance, Edgar descobre viver situações similares às do protagonista de Goethe: saída repentina da casa dos pais, situação amorosa conflituosa, repudio à sociedade, etc... Edgar habita este barracão que pertence aos pais de seu amigo Willi e mantém dali correspondência com Berlim através de fitas cassetes. Em algumas gravações enviadas ao amigo, Edgar cita trechos do romance de Goethe, que pela linguagem erudita contrasta com a sua. Edgar ainda perambula por Berlim, procura se divertir em casas noturnas ou mesmo sozinho em casa, ouvindo jazz e rock, lendo livros, pintando e fazendo troça de algumas situações

que ele próprio já viveu. É em um desses momentos que cita o romance Robinson 
Malaguti, S. - Antes da queda do Muro

Crusoe e nome do escritor americano Salinger, criador de Holden, protagonista do romance The Catcher in the Rye. Nesse ínterim, Edgar conhece Charlie, uma professora de jardim de infância, por quem fica apaixonado. Ela, porém, já é noiva de Dieter, germanista que está no serviço militar. Mesmo assim, ele mantém uma relação amistosa e, mais ao longo do romance, uma relação amorosa, ainda que curtíssima. Depois de dois meses, cansado de sua solidão e falta de objetivos, Edgar decide ser pintor de prédios e casas num grupo de trabalhadores civis. Ali se depara com muitos problemas do trabalho em grupo, tem problemas em aceitar a hierarquia e as normas estabelecidas. Edgar não suporta ficar muito tempo neste trabalho e decide desenvolver um equipamento de pintura a jato sozinho. Com a sua descoberta, ele articula comemorar seu retorno à sociedade. Mas, Edgar é atingido por um choque elétrico de alta tensão e morre. Werther, o protagonista de Goethe também tem um final fatal, suicidando-se. Contudo, a morte de Wibeau é heróica e aproxima-se à idéia de mártir, já que desenvolvia num aparelho que facilitaria a atividade de um grupo de trabalhadores. Nesse sentido, supera o destino fatal do gênio-vítima Werther que se suicida por um amor não correspondido.

Quando Plenzdorf opta por criar situações nas quais sua personagem vivencia as mesmas experiências (p. ex. sair da casa paterna, viver um triângulo amoroso, perambular pela cidade) dos textos de Goethe, Defoe ou Salinger, com novos significados, ele está imprimindo no intertexto a leitura que fez dos clássicos. No nosso caso, a leitura de Plenzdorf revela que ele é um leitor que se identificou com o romance de Goethe, já que o utiliza como base de seu próprio romance. Por outro lado, Plenzdorf se revela um leitor com aguçado senso crítico e cômico, já que caçoa de certos motivos de Goethe. Como por exemplo, deparar-se com o clássico Werther no banheiro. Esse acontecimento, que pode ser entendido como uma piada, revela-se como crítica à censura praticada pelo Partido Socialista que dificultava o acesso a textos que considerava prejudiciais à identificação positiva do indivíduo com a sociedade. Muitos elementos do romance de Goethe relacionam-se, pois, antagonicamente em relação ao projeto socialista, pois no clássico apontam para a emergência de novas experiências de socialibilidade e, principalmente para "novas concepções sobre o indivíduo, novos sentidos e tensões entre esse indivíduo e determinados papéis sociais, assim como transformações nas concepções sobre os espaços e as representações sociais” (OLIVEIRA 
Malaguti, S. - Antes da queda do Muro

2008: 15). Werther tem todos os ingredientes de uma pessoa passional e insatisfeita com normas e regras sociais, não tem um trabalho fixo nem produtivo, servindo ocasionalmente aos burgueses locais. Werther não vive em grupo ou para uma comunidade; ele pretende ser um indivíduo livre de obrigações, vive para si e para suas paixões. O único elo pessoal que mantém é com Charlotte, por quem mantém um amor devastador. Werther cultiva, portanto, o individualismo do homem moderno e representa uma figura antagônica à dos ideais socialistas.

Nem todo o comportamento de Werther é, contudo, aproveitado ou aprovado pelo personagem contemporâneo Wibeau. O motivo da morte, por exemplo, é interpretado por este de forma contrária em relação a Werther. Enquanto Werther tem prazer em morrer, desvendando um modo doentio de ser, aquele nem gosta de pensar na situação, fazendo até troça a respeito em linguagem coloquial, o que exclui dele o peso da morte voluntária que tinha no contexto do socialismo um tom negativo, já que o suicídio era visto como uma decisão arbitrária de se excluir, de se anular perante a sociedade. O suicídio pode ser visto também como o ponto culminante de um estado psicológico de depressão, no qual o sujeito, incapaz de "se dissociar da situação para analisá-la por fora ou por outra perspectiva, perde o controle de si mesmo e se entrega progressivamente à morte" (SCHERPE 1975: 37). A substituição do suicídio pelo acidente fatal é, portanto, decisiva na constituição da personalidade do protagonista Wibeau, pois ela exclui dele o comportamento doentio de Werther. Wibeau é, ao contrário de Werther, capaz de uma análise crítica de sua vida: ele não se vê como uma vítima do meio social, entende tudo com uma certa irônia e procura sempre uma saída criativa para seus problemas; e disso tudo decorre a transformação fundamental da tradição de Werther em Wibeau.

Mas, entre Werther e Wibeau há ainda Crusoe e Holden e isso significa que a transformação intertextual também passa por eles.

O primeiro é famoso na tradição da literatura de viagem. Ele deixa a Inglaterra de navio, na esperança de encontrar maior fortuna em outras terras. Após várias fatalidades, aporta em uma ilha primitiva e desabitada, onde é obrigado a viver boa parte de sua vida. Esse período de solidão, afastado da vida social, muda muito o comportamento e os valores de Crusoe. Esse texto pode ser visto como uma literatura anti-burguesa. Contudo, não é esse aspecto que Plenzdorf privilegia em sua obra. Ele 
Malaguti, S. - Antes da queda do Muro

incorpora justamente os momentos que se chocam com os ideais socialistas ao traçar paralelos entre a personalidade do protagonista e com os motivos de fuga e isolamento contidos em Robinson Crusoe. Há no personagem Crusoe muita subjetividade, volição, e, sobretudo, uma determinação pessoal típica do anseio burguês de auto-suficiência e autonomia do indivíduo economicamente produtivo (CARL 2008: 290). Crusoe tem um plano pessoal e faz de tudo para realizá-lo, demonstrando-se um ser incansável e não desistindo de seus planos, mesmo que isso seja contra a vontade de seus pais ou que lhe proponha muitos desafios. Além de sua tenacidade, Crusoe é muito prático e flexível, tentando tirar proveito do seu meio (recolhe todos os materiais que encontra na ilha para a sua sobrevivência) e todas as situações, na medida em que se adapta a elas. No final do romance, Crusoe vê seu plano realizado, apesar das adversidades que o destino lhe apresentou. Neste sentido, o romance Robinson Crusoe dá ênfase à vitória de componentes subjetivos do protagonista. A reescritura de Plenzdorf procura ativar o subjetivismo de Crusoe no protagonista Edgar Wibeau, relacionando a motivação de sua decisão ao livre exercício de sua volição, e não em função de seus pais. Percebemos, portanto, que a personalidade de Edgar Wibeau fica definida pela mesma autodeterminação e autosuficiência de Crusoe: "Jedenfalls fing ich Idiot noch am selben Tag an, die ganze olle verlassene Kolonie nach brauchbaren Gegenständen abzusuchen. (...) Ich schleppte trotzdem alles ran, was irgendwie brauchbar aussah. Erst mal Material haben, dachte ich."7 (PLENZDORF 1973: 109)

O segundo, Holden, um adolescente americano de 16 anos, nos relata, em linguagem infantil e simples, suas perambulações em Nova York depois que foge da escola. Em Nova York, Holden se depara com vários personagens, com os quais se criam situações frustrantes aos olhos do adolescente confirmando suas desconfianças de um mundo decadente. Ele é um representante expressivo como personagem da literatura que se desenvolveu a partir do final dos anos 50.

A tendência de contestação a partir desse ano foi um fenômeno mundial e não se restringiu só ao âmbito literário, pois regia entre os jovens um espírito contestatório que

\footnotetext{
7 "Bem, de qualquer forma, eu, idiota, comecei a procurar no mesmo dia por objetos úteis naquele barracão chato e esquecido. (...) Mesmo assim, eu arrastei tudo que parecesse ter algum uso. Primeiro ter o material, eu pensei." PlenZDORF, Ulrich. Die neuen Leiden des jungen W. Frankfurt a.M., Suhrkamp, 1973, p. 109
} 
Malaguti, S. - Antes da queda do Muro

os levava a se rebelarem contra as instituições políticas. Dessa postura em relação às lideranças políticas de então se formaram grupos juvenis que se expressavam com rebeldia através das artes. É o caso da geração dos Angry Young Men da literatura inglesa ou Beatniks, da americana.

Na Rússia, os jovens também se movimentariam contra a tutela intelectual do partido após a morte de Stalin em 1953 e criaram o samizdat (FLAKER 1975: 20), a circulação ampla de manuscritos e revistas de teor alternativo e marginal que apresentavam protagonistas igualmente marginais e rebeldes. Os americanos mostramse entre todos os mais radicais nessa linha de individualialismo extremo em seus protestos contra a sociedade americana, o código puritano da época e o conformismo. A prosa dos Beatniks é quase sempre autobiográfica e relata o caráter marginal e aventureiro de seus autores, que adotaram um modo alternativo de vida, aderiram a novas seitas religiosas e cometeram excessos com drogas, álcool e sexo. Nos primórdios do movimento dos Beatniks, destaca-se o romance The Cather in the Rye de SALINGER (1951).

Ao citar esse romance, Plenzdorf chama para seu texto não só o personagem, mas um paradigma da literatura do leste europeu, conhecido como prosa jeans (FLAKER 1975: 24). Trata-se de um conjunto de obras no bloco socialista que Salinger inspirou, a partir de seu The Catcher in the Rye, principalmente no samisdat, ou seja, no circuito da literatura alternativa e que não seguia às normas estéticas oficiais da então URSS. Este conjunto de obras se desenvolveu a partir da década de 60 e designa dentro da história da literatura soviética a então prosa de tom jovem ou, mais especificamente, daqueles que usavam calças jeans. No contexto da literatura do leste europeu a prosa jeans emerge da geração inconformada dos anos 60 que só podia considerar como retrógrados os modelos políticos e econômicos de suas nações que cresceram sob os preceitos rígidos de Stalin e passavam agora pela incompetência de Kruchóv. Os jovens se sentem ameaçados pelos regimes deformadores e percebem a necessidade de uma tomada de posição para a melhora de seus próprios destinos, já que das camadas mais tradicionais não poderiam esperar muitas melhorias. No meio artístico, forma-se uma ala de liberais que procuram a inovação e a defesa de uma nova estética.

A prosa jeans sempre trata do mundo de jovens e adolescentes e é necessariamente narrada por um deles. O jovem narrador observa o mundo sem 
Malaguti, S. - Antes da queda do Muro

nenhuma linha rígida do pensamento tradicional e o narra com uma linguagem irreverente: ritmo acelerado e telegráfico entrecortado por gírias, anglicismo e jargões de sua panelinha ou gangue. Toda outra linguagem fora essa é estranha e significa a intervenção do mundo adulto. Essa intervenção é vista como negativa e pode ser analisada como o uma modesta tentativa de oposição por parte do narrador. Mas, como o jovem narrador não segue os mesmos princípios do mundo adulto, que vê na concorrência, na guerra e nas armas a solução para seus conflitos, o princípio contestatório desse jovem narrador da prosa jeans é a ironia, o descaso e o disparate. $\mathrm{O}$ protagonista da prosa jeans não acredita no mundo e nos princípios que herdou e procura novas perspectivas fora daquilo que lhe foi transmitido de forma convencional. Seus valores estão dentro da cultura de rua, da cultura pop e contemporânea, e ele se empenha em acompanhar as novidades dentro desses meios. Por fim, a necessidade dos protagonistas de se manterem bem informados os leva a adquirir equipamentos eletrônicos e a usá-los intensivamente.

O romance Die neuen Leiden..., de Plenzdorf, apresenta muitas dessas características: Edgar sai de uma cidade pequena, Mittenberg, para uma outra grande, Berlim, onde faz diversas excursões por museus, discotecas, bares e lojas; utiliza constantemente um gravador portátil. Outro hábito interessante de Edgar é o de reviver personagens, situações, episódios históricos contemporâneos. Edgar recorda Charles Chaplin, Louis Armstrong (apelidado Satchmo), Sidney Poitier, a guerra no Vietnã, agitadores estudantis de 68, Ella Fitzgerald, bandas musicais da ex-RDA (M.S.-Septett, Uschi Brüning, SOK, Petrowki.), Happenings e o estilo Pop-art. Esses são elementos constitutivos através dos quais procura mexer com a tradição e com a cultura ocidental, além do muro, dando assim continuidade a esses elementos contemporâneos no espaço literário. É na inserção desses elementos que o jovem protagonista provoca e questiona o mundo dos adultos socialistas. Além disso, eles imprimem ao texto de Plenzdorf um sistema comunicativo muito peculiar, pois estabelecem uma nova linguagem de tom jocoso, irônico e descomprometido. Podemos citar os seguintes pontos:

Combinada com o estilo de vida, essa linguagem lhe possibilita a expressão repentina e improvisada do pensamento que está bem perto de uma consciência pessoal. Edgar Wibeau faz um amplo uso de expressões e palavras típicas de um adolescente sendo que os jargões e a gíria local servem para codificar a identidade do narrador, ao 
Malaguti, S. - Antes da queda do Muro

mesmo tempo que vale como meio para ironizar ou parodiar o mundo adulto e erudito. Esses hábitos linguísticos regem a maior parte da narração, de forma que percebemos a mudança drástica no nível da linguagem quando há a inserção do nível do diálogo do pai com outras personagens, o qual é normalmente formal, e as citações de Goethe. Podemos ilustrar o estilo da linguagem com os seguintes hábitos lingüísticos de Edgar ${ }^{8}$ :

- uso amplo de interjeições,

- preferência por palavras e expressões genéricas, tais como: pessoal (Leute), coisa (Zeug), coisa (Sache), coisa (Ding), cara (Kerl), fazer (machen), bobo (blöd), tudo (alles), isso (das), claro (klar), é isso (das war so), assim (einfach so), como? (wieso?);

- tendência à contração (ich's, wolln, hab),

- preferência por encadeação isocrônica de orações principais: ““"Er war dagegen. Er wollte arbeiten. Er hielt das für Kinderzeug. Genau wie das mit der Leiter." (125),

- tendência à concisão: “Stop mal, stop!”(25), “Stimmt alles"(13), “Das stimmt.”(21), “Kein Wort.”(44), “Dann läuft es.”(45), ,Im Ernst“(51),

- uso de anglicismo: "high”(30), “Show”(99), “Clown“(110), “(...) Speech"(111);

- $\quad$ uso de palavras populares ou de baixo calão: “Das war eine Sauerei."(11), “Kein Aas sagt ja auch”.(14), “Daß ich über den Jordan ging, ist echter Mist."(16), "Dazu darf man natürlich keinen fetten Hüften haben und einen fetten Arsch schon gar nicht."(27), "Ich hätte laut Scheiße brüllen können.“(75); ${ }^{11}$

\footnotetext{
${ }^{8}$ Indicaremos somente o número das páginas do texto de Plenzdorf.

9 "Ele era contra. Ele queria trabalhar. Ele achava isso brincadeira de criança. O mesmo com a escada."(125);

10 "Pera ai!"(25), “Tudo certo.”(13), "Isso mesmo.”(21), "Sem palavras.”(44), “Aí funcionou.”(45), "Sério."(51)

11 "Isso foi uma baixaria."(11), "Nenhum merda fala isso."(14), "É uma droga mesmo que eu bati as botas.”(16), “Aí não dá pra ter uma cintura gorda e uma bunda gorda, aí que nem dá mesmo.”(27), "Eu tinha soltado um monte de merda bem alto."(75)
} 
Malaguti, S. - Antes da queda do Muro

- $\quad$ uso de gírias: scharf, echt, edel, blöd, Gören, pauken, Jux, Bude, reinreden, popen, Schädel, Spinner. ${ }^{12}$

Dessas características decorre a transformação estílística na relação com o texto de Goethe, cujo estilo sentimental e rebuscado está presente somente em algumas citações no texto de Plenzdorf.

A transformação estrutural do texto de Goethe é o resultado da formatação textual, que os elementos culturais recordados por Wibeau provocam na prosa. Por exemplo, quando a canção interpretada por Wibeau é literalmente reproduzida no texto, rompe com a estrutura tradicional do romance de Goethe, que remonta ao romance epistolar de cunho intimista e elitista do século XVIII. Plenzdorf se distancia desse tipo de romance e rompe com a lógica linear causal dos acontecimentos relatados utilizando o recurso narrativo do flashback. Enquanto em Goethe as experiências de Werther, causas da frustração pessoal e, como consequência final, do suicídio, antecedem o desfecho fatal, lemos em Plenzdorf a morte de Wibeau no início do romance. Os episódios anteriores à morte vão sendo apresentados sem uma sequência lógica a partir do presente da narrativa conforme o pai de Wibeau conversa com pessoas que conviveram com Wibeau dias antes de sua morte. Wibeau, defunto, comenta o relato dos entrevistados. Em Edgar Wibeau temos, portanto, um protagonista onisciente que tece sua enunciação no presente dentro de um pequeno intervalo de tempo. O tempo do enunciado é, ao contrário da enunciação, longo, visto que o protagonista constrói a narrativa recolhendo momentos desde sua saída de casa até a morte. O que Wibeau faz é recortar os acontecimentos e intercalá-los conforme seu pai vai abordando as demais personagens.

Apesar do discurso em primeira pessoa proveniente do protagonista, ele não monopoliza a narração com sua fala, mas a intercala com o nível de diálogos diretos que corre paralelo à sua perspectiva. O foco narrativo é embaçado pela mescla de dois tipos de recursos: 1) de natureza discursiva: solilóquios, expressão imediata do fluxo da consciência, diálogo direto entre personagens e diálogo indireto entre os personagens

\footnotetext{
${ }^{12}$ jóia, mesmo, coisa fina, palhaço, baixinhos, ralar, tique, trepar, cuca, pirado.
} 
Malaguti, S. - Antes da queda do Muro

narrado pelo protagonista; e 2) de natureza intermidial: interpretação, reprodução ou comentário de música (word music) (WOLF 1999), de cinema ou de quadros de pintura.

Nesse segundo recurso particularmente, o texto literário escrito faz presentes sons, rítmos, imagens e cores, qualidades que a escritura em si não possui. Assim, quando Edgar canta a música Bluejeans, podemos ler o texto lírico como se estivéssemos escutando uma canção de jazz ou blues. Esse recurso é reforçado pela menção aos nomes de Satchmo, apelido de Louis Amstrong, e mais tarde à cantora Ella Fitzgerald. Na adaptação cinematográfica essa canção ganha um reforço performático, já que não só escutamos Edgar cantando-a, como também vemos a coreografia, a expressão facial e o guarda-roupa, que incluí, obviamente, a calça em jeans azul e cabelos longos. Edgar considera esses ritmos de echte Musik (música de verdade) que sob a denominação única de música beat eram proibidos na ex-RDA. A razão de sua proibição na Alemanha Oriental não está somente na sua origem, americana, como também no princípio desarmônico que rege esse rítmo. Na $11^{\mathrm{a}}$. plenária do partido, colocou-se, conforme JÄGER (1994: 122) que o ritmo beat era a expressão de uma era de revolução técnica e, portanto, prejudicial:

Dabei wurde übersehen, daß der Gegner diese Art Musik ausnutzt, um durch die Übersteigung der Beat-Rhythmen Jugendliche zu Exzessen aufzuputschen. Der schädliche Einfluß solcher Musik auf das Denken und Handeln von Jugendlichen wurde grob unterschätzt. ${ }^{13}$

No que se refere ao cinema, Edgar recorda gêneros, a comédia na figura de Charles Chaplin, o drama educativo (Ao mestre com carinho) e o documentário educacional típico da DDR (Pflichtfilmen für den Geschichtsunterricht). A menção ao ator carreia para o romance os primórdios do cinema, os filmes mudos em preto e branco e a figura do pícaro das telas. Quanto à pintura, Van Gogh é citado, constituindo uma bela associação à palavra campo, motivo de Van Gogh presente no romance de Salinger. O caçador em campos de centeio parece-nos, então, transportado para um quadro do pintor

\footnotetext{
13 "Não se percebeu que o inimigo se aproveita desse tipo de música para levar os jovens, por meio da aceleração dos rítmos das batidas, a cometerem excessos. A influência prejudicial desse tipo de música sobre o modo de pensar e agir dos jovens é subjulgada."
} 
Malaguti, S. - Antes da queda do Muro

holandês, decorando a ficção com cores (laranja, lilás, violeta, azul-piscina) e paisagens típicas das obras do artista.

Essa mescla na narrativa ou a narrativa mesclada é engendrada essencialmente pela perspectiva pessoal do protagonista Wibeau, cujo princípio crítico e jocoso provoca na produção textual a negação da ordem convencional de estruturação do romance do século XVIII. Contribui para tal negação a diagramação gráfica, resultado das diversas transformações intermidiais, conforme GAST (1999: 172) bem observa:

Ein wichtiger Bestandteil dieser Verfilmung ist seine interessante Geschichte: Ursprünglich schon für den Film als Drehbuch entworfen, nahm das Stück einen Unweg über ein Theaterstück, ehe es danach als Buch in der DDR und in der Bundesrepublik erschien (als Prosafassung zuerst 1973, als Taschenbuch 1976). Dazwischen lag noch eine Hörspielfassung des Bayerischen Rundfunks von 1974. Als Fernsehfilm wurde es - in der Regie von Eberhard Itzenplitz am 20.04.1976 in der ARD zum ersten Mal ausgestrahlt. ${ }^{14}$

Decorre dessas transformações intermidiais o espaçamento maior entre as linhas, o espaço maior entre diálogos e corpo de texto, as margens amplas na citação de textos de uma música ou de um livro, a ausência de capítulos; tudo isso em um escopo modesto de 148 páginas. Desta forma, o aspecto visual do texto difere muito do clássico romance epistolar, assemelhando-se ora a um roteiro de filme, ora a um texto de peça de teatro; ora a um texto de peça radiofônica e ora a um romance.

Nesse novo formato, as citações literais ao romance de Goethe são as que mais saltam aos olhos do leitor. Isso se deve em primeiro lugar à brusca mudança de tom entre as linguagens do texto novo e do pré-texto: Edgar Wibeau utiliza uma linguagem juvenil, contemporânea, cheia de gírias e quebras; a linguagem de Werther é o alemão de 200 anos atrás, portanto antiquado ou "careta" em comparação à linguagem de Edgar. No romance Edgar não aprecia o estilo de Werther, definindo-o como estilo impossível. Em segundo lugar, na maior parte das ocorrências das citações, Plenzdorf

\footnotetext{
14 "Uma parte importante da adaptação cinematográfica é a sua própria história: originariamente feita como roteiro de filme para o cinema, a peça tomou outro rumo; foi primeiro para o teatro antes que fosse publicada em livro na RDA e na RFA (primeiro em 1973, na versão em prosa, e em 1976 na versão de bolso). Nesse meio tempo, em 1974, ainda foi feita a peça radiofônica pela Rádio da Baviera. Como filme foi transmitida pela primeira vez em 20.04.1976 na ARD sob direção de Eberhard Itzenplitz.”
} 
Malaguti, S. - Antes da queda do Muro

repete uma técnica na linearização do material recortado que deixa a citação mais evidente ao receptor. Tal técnica consiste em comentário prévio e/ou posterior à citação sobre o próprio ato de citar. Conseqüentemente, as citações ao texto alheio não ficam escamoteadas.

Mas, a incorporação do material do pré-texto não é mera repetição de trechos no intertexto. Na fase de incorporação ao texto novo ela passa por um processo de modificação formal e semiótica para transformar o nível narrativo de outra mídia, o da gravação de fita K-7, que o texto de Plenzdorf pretende simular. Para tanto, o autor precisa desmanchar a seqüência do ritmo narrativo do texto de Goethe, originalmente epistolar e portanto escrito, para reproduzir na ficção do seu romance uma seqüência narrativa que tende à oralidade e passe a idéia ao receptor de que ele está escutando uma gravação em fita K-7. Por exemplo no seguinte trecho de Die neuen Leiden... de PLENZDORF (1973: 17):

Kurz und gut / wilhelm / ich habe eine bekanntschaft gemacht / die mein herz näher angeht - einen engel - und doch bin ich nicht imstande / Dir zu sagen / wie sie vollkommen ist / warum sie vollkommen ist / genug / sie hat allen meinen sinn gefangengenommen - ende $^{15}$

Conforme o exemplo acima, podemos, então, observar as seguintes transformações nas citações a Goethe : 1) substituição grafêmica da letra maiúscula de substantivos e nomes próprios pela minúscula, 2) exclusão da pontuação convencional (vírgula e/ou pontofinal), 3) adição de barras paralelas em substituição às vírgulas do pré-texto que visam a segmentação visual do texto, 4) adição de hífens em substituição aos pontos-finais, em supressão de trechos do pré-texto e/ou como indicadores de uma montagem de citações, 5) adição da palavra ende no fim de algumas citações e 6) montagem de fragmentos do pré-texto em uma única citação (primeira, segunda, sexta e sétima citação).

No final, esses processos resultam na transformação total do visual do pré-texto, mas não do nível lexical ou semântico, o que nos leva a concluir que há identificação do

\footnotetext{
15 "Rápido e bem / wilhelm / fiz uma amizade / da qual meu coração se aproxima - um anjo - e, mesmo assim, não tenho condições / de lhe dizer / como ela é perfeita / porque ela é perfeita / basta / ela tomou conta de todos os meus sentidos - fim"
} 
Malaguti, S. - Antes da queda do Muro

protagonista Edgar com os trechos citados. Essa apropriação faz-se através de uma leitura crítica do protagonista que pode ser comprovada pela supressão de trechos do pré-texto e montagem de fragmentos do pré-texto. O uso dessas técnicas demonstra que a escolha das citações não são aleatórias, porém fruto de uma seleção intencional do protagonista para atingir um determinado objetivo. De fato, Edgar usa as citações na fita para comunicar-se com Willi, explicar-lhe fatos de sua vida que ele mesmo não consegue descrever ou não quer descrever com suas próprias palavras. Nessas ocorrências, as citações se prestam ao estabelecimento de um ato comunicativo do protagonista com seu colega.

Se no início a relação de Edgar com o romance de Goethe está mais para um gibi, conforme avançamos no romance ela está mais para um livro sagrado. Verificamos que as citações do clássico não são meros elementos de adorno, são elementos expressivos do romance, já que através dela podemos descobrir aquilo que o protagonista deseja expressar. O contato com o texto literário de Goethe transforma, portanto, o potencial crítico-comunicativo de Edgar, liberando-lhe frases e palavras que até então não havia conseguido formular para situações que vive e quadros mentais que elabora.

\section{Considerações finais}

O romance de Plenzdorf contém e menciona uma série de elementos que poderiam ser considerados subversivos do ponto de vista da literatura oficial da então RDA que, no entanto, tornou o romance extremamente interessante perante a crítica. Primeiramente podemos apontar a configuração geral e básica do romance, tais como o formato e a linguagem, como extremamente acessíveis. Em seguida, a presença de diversos elementos contemporâneos da cultura ocidental, como, por exemplo, o jazz, o rock, as gírias, os cabelos longos, os jeans, a tecnologia, o urbano, a por-art e happenings que, mesmo ignorados pelo sistema socialista por serem considerados produtos do mundo americanizado e capitalista, gozavam secretamente de popularidade no regime socialista. Plenzdorf identificou esses elementos e inseriu-os em seu 
Malaguti, S. - Antes da queda do Muro

romance, provocando, assim, uma maior interação comunicativa entre ele, autor, o texto e o leitor.

Esses elementos já faziam parte do horizonte de alguns grupos intelectuais e culturais dos anos 70 da RDA, década da publicação do romance, mas pertenciam à cultura popular, informal, oposicionista ou oficiosa; e, consequentemente, não correspondiam aos ideais socialistas. Contudo, os ideais socialistas oficiais dessa década não mais combinavam com os ideais de outros membros da sociedade, como, por exemplo, os de artistas e de jovens. As determinações para as políticas culturais e literárias evidenciam que os órgãos reguladores da RDA ainda se preocupavam com a consolidação de uma cultura e identidade nacionais através de uma centralização dos universos verbal, expressivo e ideológico da nação. Suspeitavam de novidades e tentavam segurar suas divulgações, principalmente se viessem de fora do país ou do bloco socialista; pois, esses elementos poderiam carregar consigo diversas mensagens de outros modos de vida, filosofias e ideologias que deslocariam a atenção dos indivíduos de uma única perspectiva de vida, a socialista, para diversas outras, dificultando assim o trabalho de centralização ideológica da RDA.

O romance Die neuen Leiden... transpõe, contudo, esses limites e busca em outras áreas do conhecimento textos, imagens, vozes, cores e estilos que eram apresentados na literatura socialista muito discretamente ou, ainda, filtrados por pareceres negativos dos órgãos oficiais da RDA. O texto combina pelo menos mais 3 outros textos da tradição literária. O protagonista Wibeau supõe ser quatro personagens em um só. Às vezes, temos a impressão de que o protagonista é Werther de Goethe, outras vezes Holden de Salinger ou Crusoe de Dafoe e, ainda, ele, o próprio Wibeau. Ao citar outros textos, Wibeau parece nos confirmar que seu discurso pode ser a todo momento relativizado, comparado, interpretado, revisto, recriado e/ou combinado pelo leitor.

Por meio de diversos processos de transformação, Plenzdorf acaba por apresentar um romance multifacetado e não-linear, onde não prevalece um ponto fixo e nem um centro regulador na narrativa. Assim, parece que o autor polemiza com a postura dogmática da sociedade socialista no trato de algumas questões, como a arte, liberdade, educação, ensino e trabalho. O narrador do romance e personagem principal, Edgar Wibeau, é a maior prova disso, pois pela função poderia comandar a visão que 
Malaguti, S. - Antes da queda do Muro

temos do texto e ser um vencedor conforme a ideologia socialista. Ao contrário disso, ele é um "desajeitado", um jovem instável, ora rebelde, ora comportado; que se coloca em questão a todo momento e se autodenomina idiota, por desejar sempre vencer: "Ich weiß nicht, ob das einer versteht. Das war vielleicht mein großer Fehler: Ich war zeitlebens schlecht im Nehmen. Ich konnte einfach nichts einstecken. Ich Idiot wollte immer der Sieger sein." ${ }^{16}$ (PLENZDORF 1973: 147).

O fim da República Democrática Alemã não representa necessariamente o fim dessa literatura inovadora que florescia, a exemplo do romance aqui analisado. $\mathrm{O}$ trabalho que Plenzdorf pôs em prática com os traços formais, com a estética pop e com a linguagem jocosa antes da Queda do Muro segue dentro da Alemanha sem muros como uma tendência mais forte do que nunca, não só em textos de autores do leste como também nos de escritores do oeste da Alemanha. Popikone (2008) e Simple Stories (1998) de Ingo Schulze, Goodbye, Lenin! (2003) de Wolfgang Becker, Herr Lehmann (2003) de Sven Regener, Liegen lernen (2001) de Frank Goosen, Sonnenalle (1999) de Leander Haussmann, Helden wie wir (1995) de Thomas Brussig e Relax (1997) de Alexa Hennig ilustram esse curso.

\section{Referências bibliográficas}

BaCHMANN-MEDICK, Doris. Cultural Turns. Neuorientirungen in den Kulturwissenschaften. Hamburg, Rowohlt, 2007.

CARL, Mark-Oliver: (Un-)Stimmigkeiten bei Ulrich Plenzdorf. Analyse intertextueller Wiederaufnahmen in "kein runter kein fern", "Die Legende von Paul und Paula", "Zeit der Wölfe", "Karla" und "Die neuen Leiden des jungen W." Frankfurt am Main, Lang, 2008.

CORNELSEN, Elcio Loureiro. O espaço da interdição interditado pela nostalgia e pelo riso: o Muro de Berlim e a "Alameda do Sol". In: Aletria (15), Belo Horizonte, 2007, 82-97. [artigo também disponível online: http://www.letras.ufmg.br/poslit/08_publicacoes_txt/ale_15/ale15_elc.pdf]

DAFoE, Daniel. Robinson Crusoe. London, Penguin Books, 1994.

FLAKER, Aleksander. Modelle der Jeans Prosa. Kronberg/Ts., Scriptor, 1975.

\footnotetext{
16 "Sei lá. Será que alguém me entende? Esse foi talvez meu grande erro: enquanto vivi, era duro em aceitar algo. Eu simplesmente não suportava ter que engolir algo. Eu, idiota, queria sempre ser um vencedor.” PlENZDORF, Ulrich. Die neuen Leiden des jungen W. Frankfurt a.M., Suhrkamp, 1973, p. 147.
} 
Malaguti, S. - Antes da queda do Muro

EMMERICH, Wolfgang. Kleine Literaturgeschichte der DDR. Darmstadt und Neuwied, Luchterhand, 1981.

GAST, Wolfgang at al. Die neuen Leiden des jungen Werthers. In: ders. Literaturverfilmung. Bamberg, C. C. Buchners. 1993, 172-177.

GoETHE, Johann Wolfgang von. Die Leiden des jungen Werther. In: Goethes Werke. Band VI, München: Verlag C.H, 1982.

GRANT, Colin B. Literary communication from consensus to rupture. AmsterdamAtlanta, Rodopi, 1995.

HÄHNEL, Ingrid, Hans Kaufmann: Eine Literatur der achtziger Jahre, in: Deutsche Zeitschrift für Germanistik 6, 1985, 18-34.

JÄGER, Manfred. Kultur und Politik in der DDR 1945-1990. Köln, Edition Deutschland Archiv, 1994.

Jenny, Laurent. A estratégia da forma. In: Jenny; Laurent et al. Poétique: Revista de Teoria e Análise Literárias, 27, Coimbra: Livraria Almedina, 1970. 5-50.

KRISTEVA, Julia. Sémeiothiké: Recherches pour une sémanalyse. Paris, Seuil, 1969.

NöтH, Winfried. Handbuch der Semiotik. Stuttgart, Weimar, Metzler, 2000.

OlIVEIRA, Igor F. Viana de. Essas "odiosas distinções sociais": Os sofrimentos do jovem Werther e as transformações no espaço público - século XVIII. In: Revista Eletrônica Cadernos de História, vol. VI, ano 3, n. ${ }^{\circ}$ 2, dezembro de 2008, 7-15, http://www.ichs.ufop.br/cadernosdehistoria. (15/03/ 2009).

PELlegrinI, Tânia. Despropósitos: estudos de ficção brasileira contemporânea. São Paulo, Annablume, 2008.

PlenZDORF, Ulrich. Die neuen Leiden des jungen W. Frankfurt a.M., Suhrkamp, 1973.

RöHL, Ruth. Literatura e ideologia na República Democrática Alemã. In: Projekt-APPA - Revista da Associação Paulista de Professores de Alemão 3, 1988, 21-29.

SALINGER, Jerome D. The Catcher in the Rye. London, Penguin Books, 1958.

SCHERPE, Klaus R. Werther und Wertherwirkung. Zum Syndrom Bürgerlicher Gesellschaftsordnung im 18. Jahrhundert. Wiesbaden, Athenaion, 1975.

WOLF, Werner. Musicalized Fiction and Intermediality. Theoretical Aspects of Word and Music Studies. In: Bernhart, W. et al. (Hrsg.). Word and Music Studies: Defining the field. Amsterdam: Rodopi, 1999, 37-58. 